\title{
MULTIPLIER EFFECTS OF AIRPORT DEVELOPMENT ON LOCAL ECONOMIC GROWTH IN SOEKARNO HATTA INTERNATIONAL AIRPORT
}

\author{
Nabilah Ulfah', Nadaa Iqbalia Gunawan²,Muhammad Iqbal Firdaus ${ }^{3}$, \\ Muhamad Rofiq ${ }^{4}$ \\ 1. STMT Trisakti, 2. STMT Trisakti, 3. STMT Trisakti, 4.STMT Trisakti \\ corresponding author:nabilahulfah97@gmail.com;
}

\begin{abstract}
The economic growth and advancement of the transportation community will require fast, safe, and timely transportation, making the airport not only a landing and take-off only for operational activities, but after the passage of the airport paradigm becomes the gateway to the economy, tourism activities, trade, and arising in the transport network, integrated with the surrounding support areas that generate economic impact of the air transport development whose purpose seeking the process of linkage changes in one field to be one cause of change in other fields. This paper endeavors to discover the multiplier effects of airport development impacts on local economic growth. The methodology of thestudy used descriptive approach with structured interview to informants in the airport whose economic life has been affected by the sheer development of Soekarno-Hatta International Airport. The study shows that local economic activities within the airport environment have been improved in some aspects, mostly in the job opportunity for local residents which drives economic improvements of the households.

Keywords: Multiplier effects of airport, Airport development, Local economic, Economic growth, Impact of developing airport
\end{abstract}

\section{Introduction}

Airport has old paradigm that the airport is only a passive facilitator that provides services to take off and landaircrafts, loading and unloading passengers, baggage and cargo. It also provides safety equipment to support aircraft activity and movement of other mode transportation in airport environment. But now as time passes, progress of the airport in Indonesia has a new paradigm(Kurniawan, 2016).The airport focuses on balancing between operational activity and commercial activity to collect income. Airport has already become a gate of economic growth for all areas occupied by the airport.

With the new paradigm, government will open business opportunities and employment for local residents so that it can give impact to local economic growth(Awiti, Okoth, Aila, Okelo, \& Ogutu, 2013). The current airport is closely related to free trade areas, logistics centers and shopping centers and even hotels 
around the airport area, so nowadaysthe function of airports is not just becoming air transport links(Kurniawan, 2016). Especially now, there is a lot of development of infrastructure and services at the airport of Indonesia. We try to do research in the environment of Soekarno-Hatta International Airport, becauseSoekarno-Hatta International Airport is one of the largest airports in Indonesia that is being developed by the government which has many impacts for the surrounding area(Sumarsid, 2017). This research aims to prove the development of Soekarno-Hatta International Airport is able to give positive impact to the local economic.

\section{Method}

This study is descriptive withqualitative approach used with structured interviews as data completion techniques. We have prepared research instruments into written questions. With this structured record respondents are given the same questions and data collector records. The researcher conducts interviews to the parties representing the existing levels in the object by conducting research on how the impact of economic with the development of the Airport by conducting structured interviews designed and conducted to collect opinions from informants in the local economic activities within the airport environment. A structured interview is designed and conducted to collect the opinions of five from different occupation respondents.

\section{Discussion and Result}

An airport is an airstrip that is used for landing and take off of aircrafts.Passengers and/or posts are equipped with aviation safety facilities as a place of intermodal transport. The airport is a complex business that requires skill and business capability such as economics, commercial and planning at the strategic level,soit is not onlyabout the operational and technical aspects. 
The view of the airport has changed dramatically in line with its changing function from public service to a commercially oriented dynamic business. Airport activity has been supported.

Airport activity based on the principle is divided into two. They are:

1. ATS (Airport Traffic Services) / Aeronautics (Aviation Navigation Service), is a revenue-oriented product. They include PJP (International, Domestic, Overflying), Customer: Airlines, Rates: Cost Recovery, Service oriented, Highly Regulated Goverment.

2. AS (Airport Services), including PJP4U, PJP2U, Aviobridge, Counter, Car Park, Rent \& Concession, Advertising, etc.

Before the UU no. 1 2009, the two services above are managed by one institution that is Stated-Owned Enterprises(BUMN) in this case the management are from PT. Angkasa Pura I, PT. Angkasa Pura II and UPT (Technical Implementation Unit) of the Directorate General of Civil Aviation in the Ministry of Transportation. The Department of Transportation determines revenue from ATS (Air Traffic System) and and AS (Air Services) and it goes into revenue of PT. Angkasa Pura I and PT. Angkasa Pura II(Republic of Indonesia, 2009).

With the existence of Law no. 1 in 2009 and followed by Government Regulation of the Republic of Indonesia Number 77 Year 2012 About Public Company (Perum) Indonesia Aviation Navigation Service Provider Institution, Air Force Air Traffic System (ATS) was formed, so that the initial revenue from ATS (Air Traffic System) and AS (Air Services) managed by PT. Angkasa Pura I and PT. Angkasa Pura II, now ATS (Air Traffic System) was managed by Public Company (Perum) Indonesia Aviation Navigation Service Provider Institution that we know AirNav Indonesia (Indonesia, 2012).

Consequently, as the AS (Airport Service) PT. Angkasa Pura I and PT. Angkasa Pura II are looking for other revenue for airport operations, both for routine exploitation and investment. Because the airport has aimed to get income from other commercial activities, the airport has been considered to be very 
important(Hidayat, Tantri, Marlita, \& Trisakti, 2016), which is the direct impact of employment and direct income earned from airport operators. Indirect impact is derived from off-site economic activity that is attributable to the airport, the main expenditure covering food, accomodation to stay, convenience and related activities (supporting, supplier and core related). Induced impact is generated by additional rounds of spending of revenues from direct and indirect employment. The induced impact covers the multiplier effects of regional economies (i.e. multiplier effects from direct and indirect impacts, such as food suppliers and beverage suppliers for catering). Catalytic impact is an airport attraction that has no intersectoral relationship with airport activity(Percoco, 2010).

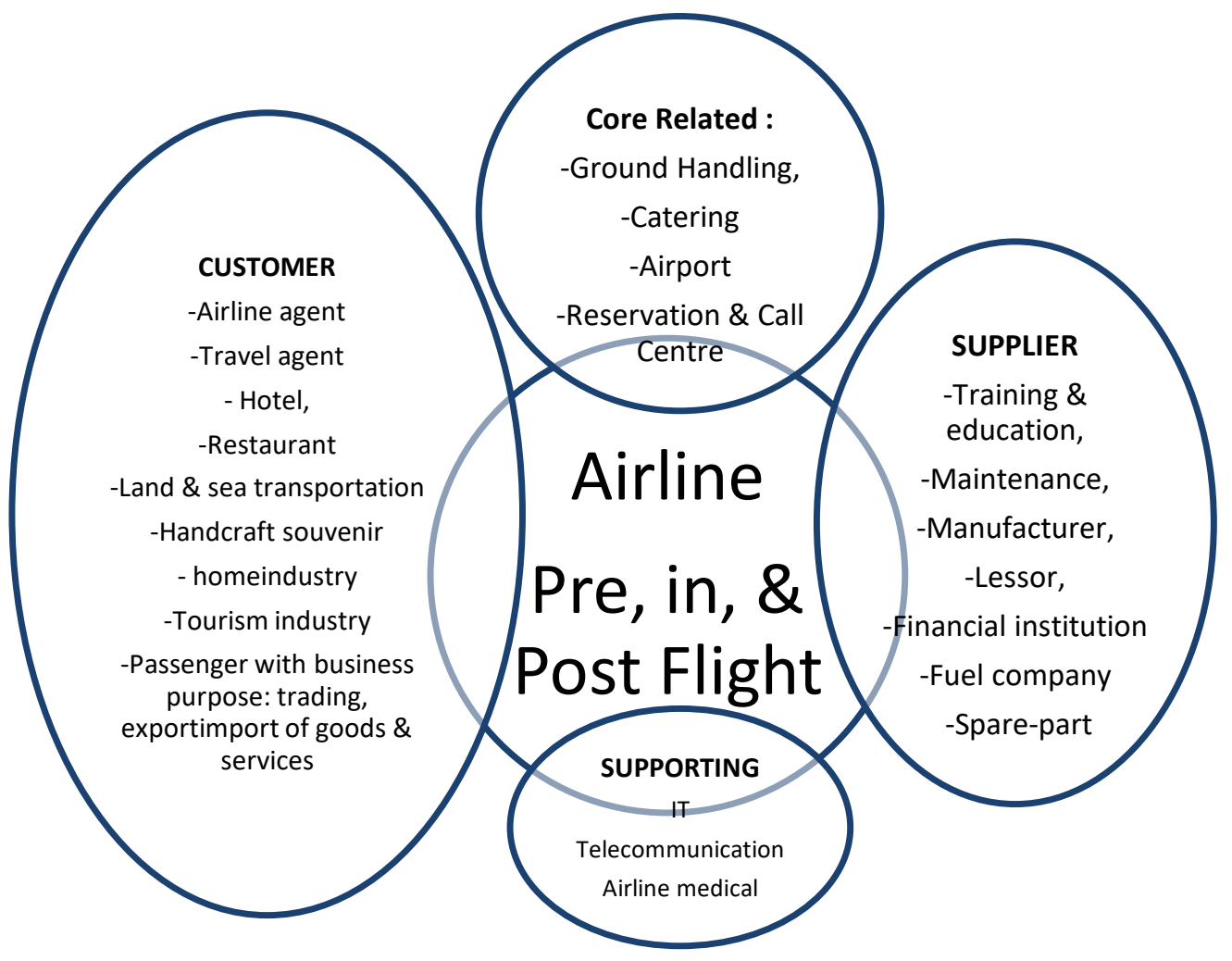

Figure 1. Interrelatedness of airport business

As we know that without airlines there will be no operational activities at the airport, the contribution generated by the activity of airlines is for salaries airlines employee and airport personal, fuel purchase, landing fees, and other 
similar purchase and expenditures purchase airport. The focus of flight activity is Pre-flight, In-flight and Post-Flight services and aactivities to complete service provided by airlines including ground handling, catering, airport, reservation \& call center. In addition to meet the needs in the field of human resources and other resources relating to the completeness of equipment and other airlines then the airport requires suppliers to provide training \& education, maintenance, manufacturer, lessor, financial institution, fuel company, and spare-part. Airlines have several layers of customers with different needs and purposes: travel agent, hotel, restaurant, land \& sea transportation, handcraft, souvenir, and homeindustry, Tourism industry, and Passenger with business purpose: trading, export import of goods \& services. Airlines also need support activities to do the activities with the IT, telecommunication, and airline medical. Thus, the above activities continue to each other field as a derivative of direct and indirect impacts.

Currently in Indonesia, the airport is being accelerated infrastructure development(Shira, 2011). transportation, one of developments at SoekarnoHatta International Airport, which is one of the largest airports in Indonesia and has a lot of influence on the economic growth of local economy, resident and national(Noor, 2012). In this study we will only discuss the effect of its development on local economic growth. Multiplier effects can be used as a measure to find out how big the role of airport development for the local worker economy. From the results of our data collection, respondents show that the impact of multiplier effects raises many important roles that arise from the process of linkage changes in one area to be one case of change in other fields(Kadarisman, Gunawan, \& Ismiyati, 2016). 


\section{Impact of local economic growth}

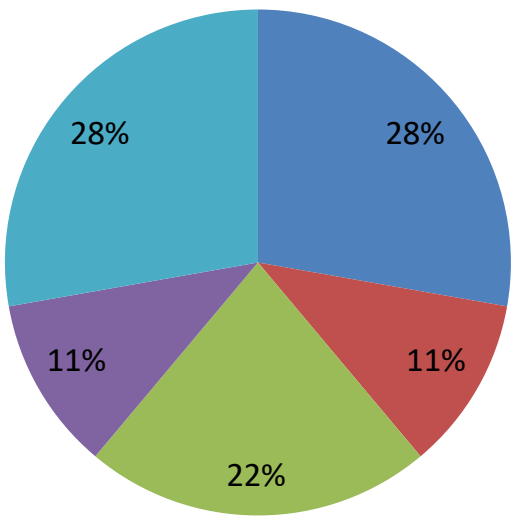

Increased revenue from before

Unemployment is reduced due to airport development

The welfare of airport workers' families increased

The existence of a new regulation that makes some of the workers become less income

Figure 2.Impact and Suggestion of the development of Soekarno-Hatta International

\section{Airport.}

Table 1. Interview Results

\begin{tabular}{|l|l|l|}
\hline \multicolumn{1}{|c|}{ No } & \multicolumn{1}{|c|}{ Impact } & \multicolumn{1}{c|}{ Suggestion } \\
\hline $\begin{array}{l}\text { Interviewee 1 } \\
\text { (Businessman) }\end{array}$ & $\begin{array}{l}\text { The existence of an economic increase in } \\
\text { the family from previous work. }\end{array}$ & $\begin{array}{l}\text { The opening of jobs to } \\
\text { communities around the } \\
\text { airport }\end{array}$ \\
\hline $\begin{array}{l}\text { Interviewee 2 } \\
\text { (Businessman } \\
\text { in airport } \\
\text { environment) }\end{array}$ & $\begin{array}{l}\text { Development of development in the airport } \\
\text { area because the airport is the main door of } \\
\text { foreign arrivals to travel to Indonesia. And } \\
\text { the compression of the business is also } \\
\text { increasing }\end{array}$ & $\begin{array}{l}\text { Economy in the airport area } \\
\text { to be more equally again. }\end{array}$ \\
\hline $\begin{array}{l}\text { Interviewee } 3 \\
\text { (Labor) }\end{array}$ & $\begin{array}{l}\text { Many friend relatives have the opportunity } \\
\text { to work in airport environments as well, and } \\
\text { salaries are more likely to increase than } \\
\text { those previously outside the airport } \\
\text { environment. }\end{array}$ & $\begin{array}{l}\text { The allowed online taxi } \\
\text { joining INKOPPOL operates } \\
\text { resulting in reduced } \\
\text { conventional taxi revenue } \\
\text { due to cheaper online taxi } \\
\text { tariff and reduced income } \\
\text { from conventional taxi } \\
\text { dispatchers. }\end{array}$ \\
\hline $\begin{array}{l}\text { Interviewee } \\
\text { (Labor) }\end{array}$ & $\begin{array}{l}\text { Welfare is increasing and employment at } \\
\text { airports can be maximized. }\end{array}$ & $\begin{array}{l}\text { Absorption of labor in the } \\
\text { area around the airport is } \\
\text { multiplied because there are } \\
\text { still many unemployed } \\
\text { around the airport. }\end{array}$ \\
\hline $\begin{array}{l}\text { Interviewee 5 } \\
\text { (Labor) }\end{array}$ & $\begin{array}{l}\text { Viable salary, intensive, health insurance, } \\
\text { pension card. }\end{array}$ & $\begin{array}{l}\text { Absorb labor in the } \\
\text { neighborhood around the } \\
\text { airport }\end{array}$ \\
\hline
\end{tabular}

Source:Research data, 2017 
From respondents interviewed, they have met the qualifications as respondents who have experience in their respective fields. The result of the development of Soekarno-Hatta International Airport gives a positive influence on local economic growth (Ricardianto, Djajaputra, \& Martono, 2017), where workers around the airport environment Soekarno-Hatta feel the increase in welfare with getting higher salary and get health insurance facilitiesfrom the airport management. Especially from the respondents who work as security officer, before the Government Regulation no. 77 Year 2012, the security workers at Soekarno-Hatta International Airport is an outsourced employee(Indonesia, 2012). However, after the issuance of the Government Regulation, they are detached from the outsourcing agency. Even security staffs get pension insurance card to support their life after they no longer become employees because of getting old(Martono \& Marina, n.d.).

As for other positive effects on local economic, the airport needs more recruitment. This happens due to the number of new facilities and infrastructures developed at Soekarno-Hatta International Airport, like the existence of terminal 3 which requires a lot of human resources for its operation from supervisor level to cleaning service level. This is proven by the presence of employees who have worked at the Soekarno-Hatta International Airport and have relatives who have received a lot of work in the airport as well.

From the perspective of respondents as businessmen who are in SoekarnoHatta International Airport environment, they also feel an increase in profit from sales. The existence of continuity between business actors and suppliers also increases local economic growth, as in the restaurant business raises the necessity to get a reliable supplier(Juliater Simarmata, Charles, \& Rizaldy, 2014).

However, there is also a negative impact, for example by permitting online transport incorporated in INKOPPOL (Parent Cooperative of the Indonesian National Police) to operate passengers from the airport. It can reduce the income of conventional taxis that exists within the airport environment SoekarnoHatta 
where the taxi drivers include people who have interests in local economic airports.

\section{Conclusion}

Currently, the concept of airport is growing wider and better known as the main gate of the country and it is very influential in the economy which is line with (Adisasmita, 2012) findings. So the multiplier effect of the airport will have a positive impact on the local economic growth, as proven by the many parties who use the opportunities of hospitality business, restaurants, real estate, andfreight forwarding business. That is, the airport will create larger jobs so it can absorb the workforce, welfare of workers in the airport environment increases and unemployment decreases(Shira, 2011).Based on the interviews obtained, many parties are hoping that labor absorption in the area around the airport that will be considered to reduce unemployment of the population around Soekarno-Hatta International Airport.

\section{References}

Adisasmita, S. A. (2012). Level Of Service Analysis And Airport Terminal Development. International Journal Of Engineering \& Technology IjetIjens, 12(2), 48-61.

Awiti, A. O., Okoth, O. S., Aila, F. O., Okelo, S., \& Ogutu, P. M. (2013). International Journal Of Business And Behavioral Sciences. Effect Of Airport Expansion On Business Opportunities In Kisumu, 3(2), 55-59.

Berjadwal, N. T., Hidayat, F., Tantri, F., Marlita, D., \& Trisakti, S. (2016). Kelayakan Pendirian Usaha Angkutan Udara. Jurnal Manajemen Transportasi \& Logistik, 3(2), 265-277.

Indonesia, R. (2012). Peraturan Pemerintah Republik Indonesia Nomor 77 Tahun 2012, 1-37.

Juliater Simarmata, Charles, \& Rizaldy, W. (2014). The Impact Of Fuel Increase And Currency Exchange Depreciation On Indonesia Aviation Industry Sustainability. Jurnal Manajemen Transportasi \& Logistik (Jmtranslog) -, 1(3), 199-208. Https://Doi.Org///Dx.Doi.Org/10.25292/J.Mtl.V1i3.18

Kadarisman, M., Gunawan, A., \& Ismiyati, I. (2016). Kebijakan Manajemen Transportasi Darat Dan Dampaknya Terhadap Perekonomian Masyarakat Di Kota Depok. Jurnal Manajemen Transportasi \& Logistik, 3(1). 
Retrieved From Http://Www.Ejournal.StmtTrisakti.Ac.Id/Index.Php/JMTRANSLOG/Article/View/72

Kurniawan, J. S. (2016). Jurnal Perhubungan Udara. Implementation of Aerotropolis Interaction Concept Based Spatial In Indonesia, 195-202.

Martono, K., \& Marina, S. (N.D.). Domestic Air Transport Regulations In Indonesia, 3(1), 1-19.

Noor, A. R. And E. S. (2012). Indonesian Journal Of Business Administration. Investmen Analysis And Business Scheme For The New Cargo Village In Soekarno-Hatta International Airport, 1(8), 572-578.

Percoco, M. (2010). Airport Activity And Local Development: Evidence From Italy. Urban Studies, 47(11), 2427-2443. Https://Doi.Org/10.1177/0042098009357966

Republic Of Indonesia. (2009). Aviation Law. Https://Doi.Org/10.1017/CBO9781107415324.004

Ricardianto, I. P., Djajaputra, D. G., \& Martono, P. D. (2017). Air Transport And Tourism In Indonesia. IOSR Journal Of Applied Chemistry, 10(5), 01-19. Https://Doi.Org/10.9790/5736-1005010119

Shira, D. (2011). Master Plan Acceleration And Expansion Of Indonesia Economic Development 2011-2025 Economic Development 2011-2025.

Sumarsid. (2017). Journal Of Economics And Business Aseanomics ( Jeba ). Analisis Kualitas Pelayanan Di Saphire Lounge Bandar Udara Internasional Soekarno-Hatta Terhadap Kepuasan Pelanggan, 2(1). 